\title{
Leisure Shopping and Fashion Tour, New Elements of the Marche Tourist Offer
}

Citation: E. Nicosia (2020). Leisure Shopping and Fashion Tour, New Elements of the Marche Tourist Offer. Bollettino della Società Geografica Italiana serie 14, 3 Special Issue: 105-115. doi: 10.36253/bsgi-999

Copyright: (c) 2020 E. Nicosia. This is an open access, peer-reviewed article published by Firenze University Press (http://www.fupress.com/bsgi) and distributed under the terms of the Creative Commons Attribution License, which permits unrestricted use, distribution, and reproduction in any medium, provided the original author and source are credited.

Data Availability Statement: All relevant data are within the paper and its Supporting Information files.

Competing Interests: The Author(s) declare(s) no conflict of interest.

\section{Leisure Shopping e Fashion Tour, nuovi elementi dell'offerta turistica marchigiana}

\author{
ENRICO Nicosia \\ Dipartimento di Scienze Cognitive, Psicologiche, Pedagogiche e degli Studi Culturali, Uni- \\ versità degli Studi di Messina, Italy \\ E-mail: enicosia@unime.it
}

\begin{abstract}
In the last decade, the Italian region Marche has consolidated a respectable position in the national and international panorama of tourist destinations. A region, that in building its territorial brand, has used its peculiar mix of past traditions and modern innovations to offer tourists a complex territorial product. This blend of natural, cultural and historical resources succeeds in appealing and attracting even the most demanding visitor. Purchasing goods during a holiday has always been a significant activity of the tourism macro- industry, both from the economical and experiential point of view. Within the variable framework of the tourism market, where destinations and operators have to adapt and enhance their offer to better attract their targets, analyzing how shopping could be a primary, secondary or ancillary reason for traveling, is a matter of crucial interest. Such travels can require short movements, typically one-day or week-end trips, but can also be characterized by a longer duration where other experiences, besides shopping, are combined. This phenomenon and its demand have historically involved Italy, a country that can rely on a diversified and high-quality offer that valorizes and combines traditions, expertise and local products along with the offer of big international brands. Among the various itineraries offered, the ones that connect places of tradition, industriousness and local craftsmanship to areas designated to prestigious fashion brands and clothing outlets, are of particular interest. The incorporation of shopping activities within a vivid framework of traditional entrepreneurial businesses is both a pleasant and advantageous experience. It represents the opportunity for a renewed exploration of the area and the rediscovery of the best local production companies. The objective of this work, through a field survey and interviews with tourists, entrepreneurs and workers of these sectors, is to investigate the phenomenon in its territorial consistency in order to understand if there is a substantial cause and effect relationship between the two sectors.
\end{abstract}

Keywords: leisure shopping, shopping tourism, tourist offer, Marche.

Riassunto. Le Marche nell'ultimo decennio hanno consolidato, nel panorama nazionale ed internazionale delle destinazioni turistiche, una posizione di tutto rispetto. Una regione che nel costruire il suo brand territoriale ha utilizzato quell'atmosfera mista di tradizioni e innovazioni, per offrire al turista un prodotto territoriale complesso, che integrando insieme risorse naturali, culturali e paesaggistiche riesce a stupire e affasci- 
nare anche il visitatore più esigente. Lattività di acquisto di beni durante il viaggio è da sempre una componente rilevante, sia dal punto di vista economico che esperienziale. Quanto appare interessante, nel quadro mutevole del mercato turistico, in cui destinazioni ed operatori si ritrovano ad adattare e potenziare la propria offerta per attrarre al meglio i propri target di doman$\mathrm{da}$, è analizzare in dettaglio quanto lo shopping sia oggi motivazione (primaria, secondaria o accessoria) dello spostamento. Si tratta di viaggi che possono tradursi in spostamenti brevi (week-end), oppure estendersi ad un più ampio arco temporale durante il quale altre esperienze si combinano a quella dello shopping. Questo fenomeno e la relativa domanda oggi coinvolgono le Marche, regione che può contare su un'offerta differenziata e di qualità che valorizza e combina tradizione, competenze e prodotti locali con l'offerta di grandi marchi internazionali. Tra i vari itinerari offerti, piuttosto interessante è quello che lega i luoghi della tradizione dell'operosità e dell'artigianato tipico ai rinomati outlet della moda e dell'abbigliamento. La tipicità s'incontra con lo shopping, in un'esperienza piacevole e vantaggiosa: un modo nuovo per esplorare il territorio e riscoprire le eccellenze delle migliori realtà produttive locali. Obiettivo del presente lavoro, attraverso un'indagine di campo e l'effettuazione di interviste, è investigare il fenomeno nella sua consistenza territoriale al fine di comprendere se esiste una sostanziale relazione di causa ed effetto tra i due settori.

Parole chiave: shopping ricreazionale, shopping tourism, offerta turistica, Marche.

\section{Introduction}

Purchasing goods during a holiday has always been a significant activity of the tourism macro-industry, both from the economical and experiential point of view. It is thus a matter of interest analyzing in depth how shopping, within the variable framework of the latest tourism market, has become nowadays a primary, secondary or accessory reason for traveling. As highlighted by Sciarelli and Rossi (2007), clarifying the role played by the shopping industry in a tourist destination is a complex operation even though it is evident that the commercial facilities of the territory can affect tourists' decision-making in choosing a destination. "In terms of economic effect, tourism can diversify the local economic structure and reduce imbalances and gaps by creating opportunities for income and employment in the region. Foreign exchange serves a key function in overcoming difficulties, such as deficits in foreign trade, as its ultimate contribution to local and national economic growth is significant. The development of travel packages for shopping tourism can become important and economical because of the substantial earnings from foreign trade and exchange of currencies from tourism" (Choi, Heo, Law 2015, 2). Such travels can require short movements - typically one-day or week-end trips - but can also be characterized by a longer duration where other experiences, besides shopping, are combined. This phenomenon traces its roots back in the US of the early 30 's but starts spreading in Italy soon after the opening of the first shopping centers and the rise of a diversified and high-quality offer that valorizes and combines traditions, expertise and local products along with the offer of big international brands. As Rabbiosi says (2016, 415) "During the late 1990s, into the first decade of this millennium, several cities began advertising shopping experiences to tourists, alongside with more traditional themes, such as heritage and cultural tours (Evans 2003; Gotham 2002; Law 2002). Promoting leisure shopping sites, events and itineraries characterizes late consumer capitalism signifying the importance of a city's brand image (Rabbiosi 2015b)".

The increase of leisure shopping, no longer subordinate to the fulfillment of basic needs, together with the rise of mass tourism, has strengthened the relationship between shopping and tourism, thus fostering new opportunities for tourist destinations and increasing the number of visitors and tourist shoppers. Moreover, it has provided an excellent way of diversifying local tourist offer by taking advantage of the top-notch territorial productions. Nowadays shopping is more and more linked to leisure time activities and is often a strong motivational push for choosing a certain holiday. Thanks to the progress of modern technology in many fields, transport and payment sectors for instance, people have acquired a wider range of mobility and buying options so a side activity like shopping can really become the main reason for picking a precise tourist destination (Alunno et al. 2012; Moscardo 2004, McIntyre 2012, Rabbiosi 2013, 2015a). Indeed, the need and desire to indulge in shopping activities has become a main stimulus for setting out on a journey and is the result of people's need to rest, their wish to escape their daily routine and the acceptance of challenges implied by shopping (Jackson 1991; Rojek 2005; Kim, Timothy, Hwang 2011; Rabbiosi 2011). Tourists seek both pleasurable and practical shopping experiences. Although tourists may not actually purchase products, the activity can still provide them with pleasure (Jansen-Verbeke 1991; Choi, Heo, Law 2015).

This phenomenon and its relative demand strongly affects Italy, especially if we consider cities like Milan and Rome which have become top luxury shopping destinations. Via Montenapoleone and Via della Spiga mark the famous fashion quadrilateral in Milan, where as 
Piazza di Spagna with its historic Caffè Greco in vogue since 1760 and via Condotti, where Bulgari opened its first store in 1905, represent the crucial shopping hub of the city of Rome. Milan is the third European city in terms of number of luxury brand stores strategically located on streets with high pedestrian flow. This urban area, historically dedicated to shopping, is one of the most sought-after European destination not just by luxury retail businesses but by international clothing brands who also attract numerous tourists. Millenials in particular, choose to buy luxury goods in the most important European shopping streets but also like shopping in extra-urban locations that play a significant role the in the geography of commerce, hence turning shopping malls, outlet villages and factory outlet stores in true and proper tourist destinations (Jackson, Thrift 1995; Graziano, Nicosia, 2013; Nicosia 2016).

Similarly, the Marche region which counts a diversified and high-quality offer that valorizes and combines traditions, expertise and local products along with the offer of big international brands, has lately seen the rise of tourism connected to leisure shopping. Among the various itineraries offered, the ones that connect places of tradition, industriousness and the popular craftsmanship of the Fermo and Macerata area, to the luxury clothing stores, are of particular interest. The incorporation of shopping activities within a vivid framework of traditional entrepreneurial businesses is both a pleasant and advantageous experience. It represents the opportunity for a renewed exploration of the area and the rediscovery of the best local production companies.

In this context, the relationship between shopping and tourism takes on a complex meaning. Tourism is an important industry which has an impact on each country's GDP and represents one of the most important cultural activities of contemporary society (Urry, Larsen, 2011). Clearly, the present pandemic situation caused by the spread of the COVID-19 which is devastating economies on a global scale, has had serious repercussions in the tourist sector, marking severely the present season and inflicting a tremendous blow at the direct and induced occupation. Tourists' behaviors and their way of traveling in the aftermath COVID-19, especially in the short run, will undergo a drastic change and it is a common belief that this can further slow down the process of economic recovery in reference to the entire tourist sector with serious consequences for the all the workers involved in the tourism business (lay-off schemes, unemployment, shutting down of business activities). This present work's attempt to analyze the phenomenon of shopping tourism in the Marche area is the result of a field survey and interviews with tourists carried out between June and September 2019 with the objective of understanding the present relationship of these two sectors - within the territorial context subject of study trying to identify the current trends and mapping new directions for future researches. Moreover, this article aims to contribute, by bringing a social and cultural perspective, in examining the nexus between tourism and consumption as it is performed in space through leisure shopping.

\section{The role played by shopping in the tourist offer of a territory}

The urge to embark for a shopping travel is either due to the need to purchase goods that are available only in particular places or to the need to reach production areas that are well-known for specific products. Going around stores, looking at shop windows, visiting markets and fairs, buying typical food and wine products, whether it is for personal use, making a gift or taking a souvenir home, represent for the tourist fundamental activities required for the fulfillment of those needs that make each travel unique. The moment the purchase takes place, the tourist literally gets in touch with the objects, the people and the culture of a particular place. Going shopping also implies a set of interrelated practices rooted in contemporary consumer society and deeply connected to particular economic, social and cultural dynamics that have helped shaping the identity of this phenomenon in its modern sense (Zukin 2004; Zukin, Smith Maguire 2004). Leisure shopping is a popular activity, particularly during holiday trips and vacations; it is one that not only modifies the structure of the shopping space in tourism places (Snepenger et al. 2003) but also has a pervasive impact on places that were not originally intended as leisure shopping spaces in the strictest sense (Bærenholdt et al. 2004; Tosun 2007; Rabbiosi 2011). Shopping becomes therefore an intrinsic part of the touristic and traveling experience. Nowadays shopping is no longer perceived as a marginal activity but as the main drive for setting out for a trip. In analyzing the relationship between shopping and tourism, two categories can be outlined. The first is where shopping is regarded as a collateral traveling activity and takes place for other reasons. The second, refers to specific touristic mobility where shopping is the trip's main purpose (Timothy, Butler 1995). Setting off for a journey has an impact on a tourist's buying habits. With this in mind it can thus be stated that shopping tourism is a form of contemporary tourism in which the purchasing of goods that do not belong to a person's daily environment is the 


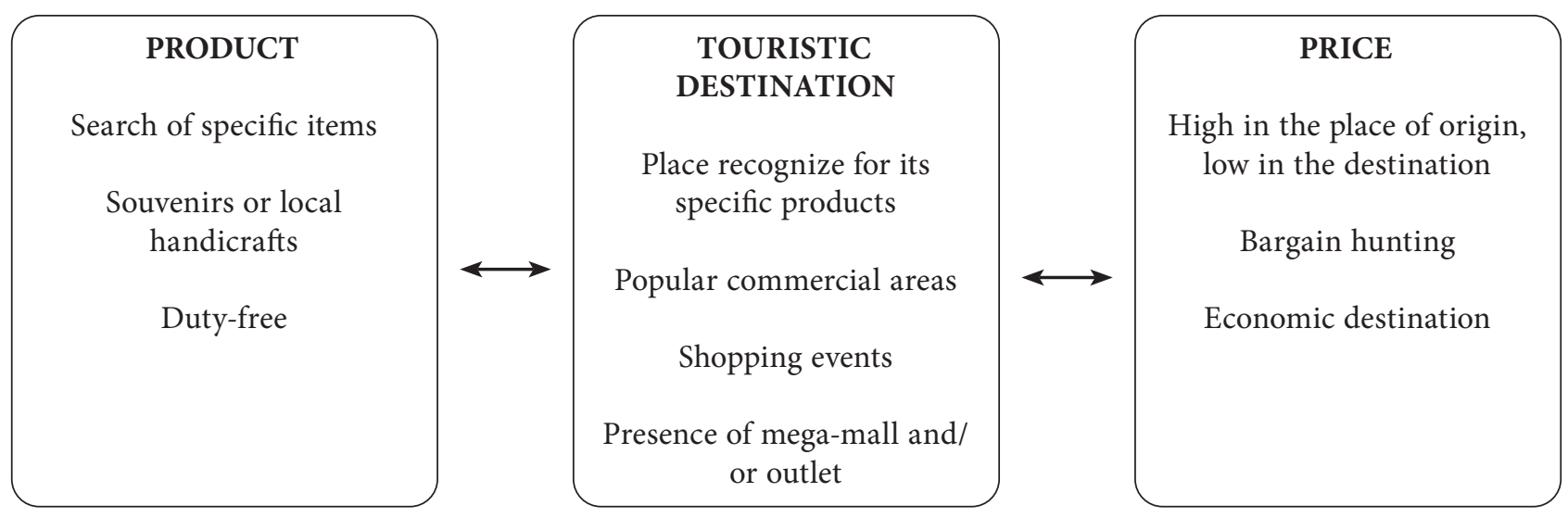

Figure 1. Factors influencing shopping as a motivation for travel. Source: author's elaboration from Timothy 2004.

key factor in choosing to travel. In regards to travelers' reasons for reaching specific tourist destinations, Timothy (2004) has identified three main factors that contribute in making shopping the primary traveling reason (Fig. 1): the product to purchase, the tourist destination and the convenient price.

Many tourists seek special brands being well aware of the product's high-quality and iconic design. Others prefer duty-free shops where they can purchase goods without paying taxes.

These shopping destinations have become famous tourist sites because they were specifically planned to meet this intention and thanks to their well valued and appreciated offer, the association of these sites to their typical territorial production is very common.

A last factor that affects tourists' decision-making in choosing a destination is the convenient price. If the tourist had no economic advantage, reaching a specific site would not be of any particular interest. The fact that tourists seek offers that are good value for money is further shown by the increasing popularity gained by outlet and company stores in recent years.

With respect to the economic advantage that is linked to the phenomenon of shopping tourism, a particular mention to the practice known as cross-border shopping is necessary. The latter can be considered a touristic phenomenon as it involves the movement of visitors from their hometown, the access to touristic infrastructures, the various on-site expenditures and whatever is ascribable to tourism. Economic, legal and social differences encountered on the other side of each frontier create attracting conditions for all sorts of tourists who are thus encouraged to go cross-border shopping for the sake of convenience. Some of these reasons include: favorable currency exchange, high tax gap between the two countries, wider range of goods and facilities compared to the home-country, wider range of brands, luxury brands and top-quality products, more flexible opening times and days. Cross-border shopping is pleasurable since the traveling is perceived not only in functional terms but also and especially as a leisure and entertainment activity.

Today more than ever, locations that allow a more articulate shopping experience whilst meeting consumers' needs are preferred. The experience of a tourist shopper is thus linked to the destination chosen for his/ her vacation.

\section{Methodology}

The survey was held between July and September 2019 and was carried out in the Marche region among the factory outlet stores located in the districts between Fermo and Macerata. This is a well known shopping area outside the city boundaries with a strong pull that attracts and moves tourist shopper flows in and out of the city.

The data provided by the Chamber of Commerce of Macerata in regards to the distributional format of the factory outlet stores located in the Macerata district, shows that the vast majority of shops are linked to the clothing and footwear industry.

Most of the factory outlet stores are situated near the industrial area and often inside it. In other cases, factory outlet stores are located in the shopping areas or in the city center but always at a short-distance from the production sites. Only a very few outlet stores are positioned outside the Marche region.

The empirical part of the survey was constituted by face-to-face questionnaires conducted in the shopping areas of Casette d'Ete (FM), Montegranaro (FM), Porto 
S. Elpidio (FM), Piediripa (urban fraction of Macerata) and Civitanova Marche (MC). These questionnaires were held over different days within a certain time-period in order to cover a wider representativeness of the sample that was randomly chosen.

Italian and foreign tourists were asked questions concerning their personal characteristics, traveling behaviors when visiting the chosen destination, information connected to the purpose of their travel and the incidence or presence of shopping among their motives.

Finally information was collected specifically concerning their shopping expenditure during their travel, not counting expenses for traveling, accommodation, food and tourist attractions (for example museum or park entrance fees).

Tourists were asked to breakdown their shopping expenditures in ten macro-categories including products like accessories (jewelry and leather goods) and design objects (furniture).

For each area, 50 valid questionnaires were collected. In case of tourists found on-site before the stores' opening times and therefore without having had the chance to perform any type of shopping activity, the choice was made to interrupt the interview in order to use only significant answers that are truly useful for data-collection and data-analysis processes.

Local residents, commute workers, as well as newly arrived tourists who had not yet started their shopping activities, were excluded from the survey. Information concerning tourists in their final stage of their visit was privileged over information regarding newly arrived tourists who were generally not included in the sample. The answers of tourists who had not performed any type of purchase were also taken into consideration when making calculations.

\section{The fashion tour in the Marche: the investigation field}

The Marche Region has been the protagonist of an economic miracle. It presents itself to visitors and tourists with its highly-productive environment and the vivid economy of its territory marked by a widespread distribution of medium and small sized businesses and highly-specialized production districts.

The peculiar structure of the region's economy was also analyzed by the economist Giorgio Fuà who even coined the term "The Marche Model". The latter was based on the strong bond that linked the industrial network to its urban tissue. This region has been capable of hosting some of Italy's biggest factory districts by adopt- ing a modern productive system based on innovation and high-quality exports whilst preserving the typical family dimension that was deeply rooted in this territory's social structure.

The manufacturing and white goods factories, the naval and musical instrument businesses together with the fishing and wine industries are but some of the economic activities that mark this region. It is in close proximity to the main production areas of top manufactured goods, scattered across the extra-urban and peri-urban land, that factory stores and outlet malls have proliferated before being incorporated in the complex network of relationships (territory-inhabitants-users) and characterizing the area's outlook and functions (Nicosia, Porto 2015).

Top-quality products combined with the expertise of local artisans are the secrets behind the success of many small businesses that have managed to become world-leading brands. These local productions, whichever sector they are connected to - food and wine, footwear or manufactured goods - are the epitome of quality, reliability and convenience. The proximity of many tourist attractions to popular factory outlet stores set the grounds for a locally-customized tourist offer (for example the tour operator Esitour). The holiday package offered to tourists and visitors includes accommodation and a guided shopping tour with a personal shopper.

On this matter it is worthwhile taking notice of an initiative promoted by Regione Marche (www. destinazionemarche.com) aimed at offering tour packages designed around the shopping offer of local factory outlet stores.

This initiative involves the making of a multimedia guide (static and interactive) with content related to local company and factory stores according to previously made agreements. The guide is uploaded on the website www.in-outlet.it (where other regions like Abruzzo, Umbria and Emilia Romagna are also featured) and further access to the link is also found on the region's tourism portal within the section named made in Marche. The latter is specifically reserved to thematic routes which are considered a main asset in the development of a sustainable form of regional tourism. This thematic route network includes itineraries connected to topnotch food and wine products as well as shopping tours that take place either within the urban center along the streets where local artisan shops are based or outside the city walls, where the destinations are factory stores and famous company shops. The In-Outlet network also includes the creation of a special discount card for tourists and an exclusive app designed to enhance the shopping experience. The know-how gained in the In-Outlet 
project was also used for two spin-offs called Shoptour and In-Outlet Online Village. The first aims at promoting short tours (mainly weekend trips) which combine shopping activities in outlet stores. The second has the purpose of creating a virtual village where local businesses can open their customized online shops, thus encouraging virtual visitors to purchase goods during their digital tour.

A travel to the Marche can therefore be an opportunity for combining the classic cultural tour or beach holiday with a shopping tour by taking advantage of the numerous top-quality goods offered by the several factory stores spread across the region.

The main factory districts worthwhile visiting during the fashion tour are two. The textile one located near Ancona and Italy's biggest footwear district situated between the provinces of Ascoli, Fermo and Macerata. Montegranaro and Casette, for instance, two towns in the province of Fermo where Tod's luxury head quarter of the Della Valle family is based, have a secular history in the manufacturing of quality shoes. The manufacturing of leather is a very old tradition in the Marche. Montegranaro in fact, also hosts luxury outlet stores of the Rossi shoe company as well as the brand Zeis Excelsa which manufactures and distributes for companies like Cult, Merrell, Harley Davidson and Bikkembergs. Another famous production/selling site is that of the Nero Giardini brand based in Monte San Pietrangeli. As far as menswear is concerned, a hot shopping spot is Filottrano a small town in the Ancona province where back in the 70's many tailoring boutiques like Lardini, Tamantini and Luca Paolorossi started their businesses. Montappone instead, is the heart of the hat manufacturing production and it is known as the International Hat Centre. The pretty village of San Biagio Osimo, always within the jurisdiction of Ancona, hosts another important outlet store that sells a wide range of top Italian brands for youth clothing like Malizia, La Perla and Naj Oleari.

The world of factory outlet stores in the Marche appears very heterogeneous and often hyper-specialized. It ranges from fashion stores, to shops specialized in designer kitchen accessories, to emporiums dedicated to lamps and home furnishings. An attractive target for kids can also be found close to Recanati where there is a district entirely dedicated to the toy industry. Here too there is the opportunity of spending time shopping along the lovely streets of the Marche's city centers. In Urbino the shoe brand Piero Guidi boasts an exclusive boutique located in the historic Raffaello Gallery right in the town's heart. In Fano, instead there is the chance of purchasing shabby-chic footwear directly in the laboratory Folets of the artisan-philosopher Andrea Traina who aims at a zero-impact production by choosing to manufacture only hand-made products using exclusively Italian and naturally-tanned leathers. The famous beachwear brand Emamò has an exclusive outlet in Fabriano which is also worth visiting.

Moving towards Matelica, in the province of Macerata, we find one of Italy's most famous fashion designer's store, the Armani Factory Outlet. In Tolentino, a small village in the heart of the Macerata province, there is also the company store of the fashion designer Nazareno Gabrielli.

Finally, in Pesaro, you can find the Outlet Freeport, - owned by the company licensed in Europe for the brands Ralph Lauren, Timberland and Husky - and the Union Moda Factory Outlet which covers a surface of roughly 2000 squared meters and sells a vast variety of Replay designer clothes and accessories.

According to the 2017 Report of the SymbolaUnioncamere Foundation which annually analyses the contribution of culture and creativity to the economy of Italian regions, the Marche, especially the provinces of Ancona and Macerata, record a strong impact on Italy's cultural-creative production thanks to the quality of the manufacturing tradition of its factory-selling districts.

The widespread distribution of small and medium sized businesses combined to the presence of important and highly-specialized production districts of clothing, accessories and manufacturing goods have helped shaping the lively economic and commercial scenario that is peculiar to the Marche region (Graziano 2019; Sfodera 2013).

This territorial configuration of highly-specialized micro-systems which form a clustering of the finest production districts constitutes the distinctive brand of the Marche region and represents the heart of the globally known trademark made in Italy.

The rise of company stores, factory stores and stock clearance shops has taken place right next to the main manufacturing and production areas that mark the extra-urban and peri-urban landscapes of the region. This phenomenon has re-shaped the land's functional asset and visual appearance influencing the complex network that governs the relations between people, territory and users (Betti et al. 2011; Perna 2012; Nicosia, Porto 2015).

Most of the single-brand factory outlet stores and stock clearance shops are mainly based in the provinces Macerata (22) and Fermo (47) (Tab. 1). The number drops in Ancona (25) and Ascoli Piceno (3) where the production mainly involves the manufacturing and design industry (Fondazione Symbola-Unioncamere, 2017). 
Table 1. Outlet list of the Macerata-Fermo district.

\begin{tabular}{|c|c|c|}
\hline Municipality and province & Outlet & Address/location \\
\hline Corridonia (MC) & Santoni Factory Outlet & Via delle arti, 79 \\
\hline Monte San Giusto (MC) & 2 GI CI srl (MgMagica) & VIA PAPA GIOVANNI XXIII, 75/79 \\
\hline Monte San Giusto (MC) & BVM Shoes (Bellini) & Via Martin Luther King, 5 \\
\hline Civitanova Marche (MC) & Falc (Naturino-Voile Blanche) & Contrada San Domenico, 24 (Civitanova Alta) \\
\hline Monte San Giusto (MC) & Fornarina & $\begin{array}{c}\text { Largo Minnucci 35-39 Villa San Filippo di } \\
\text { Monte San Giusto (MC) }\end{array}$ \\
\hline Corridonia (MC) & Antonio Maurizi & Via Enrico Mattei, 133 \\
\hline $\begin{array}{l}\text { Civitanova Marche (MC) e Porto San Giorgio } \\
\text { (FM) }\end{array}$ & Andrea Morelli & $\begin{array}{l}\text { Via Luigi Einaudi, } 428 \text { (Civitanova) e Borgo } \\
\text { Fratelli Rosselli (Porto San Giorgio) }\end{array}$ \\
\hline Civitanova Marche (MC) & Barleycorn & Via Lauro Rossi, 16 \\
\hline Monte San Giusto (MC) & Baby Ketty & Via San Giacomo, 12 \\
\hline Monte San Giusto (MC) & CRM (Camerlengo) & Via Madonna Concezione, 70 \\
\hline Morrovalle (MC) & Moma & Via Martin Luther King, 9 \\
\hline Monte San Giusto (MC) & Lepi & Via del Lavoro, 27 \\
\hline Civitanova Marche (MC) & Bamboletta & Via Sonnino, 47 \\
\hline Montecosaro (MC) & Giorgio Zamponi & Via Crivelli, 22 \\
\hline Monte San Giusto (MC) & Zecchino d'Oro & Via Purità, 128 \\
\hline Monte San Giusto (MC) & Cherie (AFG srl) & Via Macerata, 326 \\
\hline Civitanova Marche (MC) & King & Contrada San Domenico, 20 \\
\hline Monte San Giusto (MC) & Fabi & Via Bore Chienti, 5 \\
\hline Morrovalle (MC) & Il Gergo & Via Gentile da Fabriano, 66 \\
\hline Corridonia (MC) & Novarese & Via della Tecnologia, 15 \\
\hline Montecosaro (MC) & Manas & Via Piceno, 2, Montecosaro Scalo \\
\hline Civitanova Marche (MC) & Strategia & Via Enzo Ferrari, 17 \\
\hline Civitanova Marche (MC) & Cesare Paciotti & Via Pirelli, 6 \\
\hline Monte Urano (FM) & Gallucci & Viale I maggio \\
\hline Sant'Elpidio a Mare (FM) & Roberto Botticelli & $\begin{array}{c}\text { Strada Provinciale Brancadoro -Località } \\
\text { Casette d'Ete }\end{array}$ \\
\hline Falerone (FM) & Fiorangelo & Via Molino Vecchio 1/C \\
\hline Fermo & Andrea Montelpare & Via Carlo Concetti, 21 \\
\hline Porto Sant'Elpidio (FM) & Lautre chose & Via Mare Egeo 9/13 \\
\hline Sant'Elpidio a Mare (FM) & Cappelletti & Contrada Brancadoro, Casette d'Ete \\
\hline Sant'Elpidio a Mare (FM) & Bimbi belli & Via Leonardo Da Vinci, 10 Casette d'Ete \\
\hline Montegranaro (FM) & Fausto Ripani & Via del Castello \\
\hline Porto Sant'Elpidio (FM) & Malloni & Via dell'Industria, 18 \\
\hline Monte Urano (FM) & Iacovelli (Linea bimbi) & Via Papa Giovanni XXIII, 51 \\
\hline Porto Sant'Elpidio (FM) & Le Silla & Via San Crispino, 37 \\
\hline Sant'Elpidio a Mare (FM) & $\begin{array}{c}\text { Premiata, Lanciotti De Verzi, Prada, Sergio } \\
\text { Amaranti, Il Gergo }\end{array}$ & $\begin{array}{l}\text { Il Castagno Brand Village, Strada Brancadoro- } \\
\text { Casette d'Ete }\end{array}$ \\
\hline Sant'Elpidio a Mare (FM) & Tod's, Roger Vivier e Hogan & Via Filippo Della Valle, Casette D’Ete \\
\hline Sant'Elpidio a Mare (FM) & Vittorio Virgili & Strada Provinciale Faleriense, 3261 \\
\hline Porto Sant'Elpidio (FM) & Loriblu & Via dell'Economia, 9 \\
\hline Montegranaro (FM) & VRL Lattanzi & Via Alpi, 143 \\
\hline Municipality and province & Outlet & Address/location \\
\hline Porto Sant'Elpidio (FM) & Icone & Quartiere Corva \\
\hline Monte Urano (FM) & Florens & Via dell'Artigianato, 1 \\
\hline Montegranaro (FM) & Damiano Chiappini & Via Adone Zoli \\
\hline Montegranaro (FM) & Rodolfo Zengarini & Via Dei Monti, 210 \\
\hline Sant'Elpidio a Mare (FM) & Formentini & Via Leonardo Da Vinci, 24 \\
\hline Montegranaro (FM) & Marilungo & Via Alessandro Manzoni, 51 \\
\hline
\end{tabular}




\begin{tabular}{|c|c|c|}
\hline Municipality and province & Outlet & Address/location \\
\hline Porto Sant'Elpidio (FM) & Dario Ciotti & Via Del Progresso, 6 \\
\hline Montegranaro (FM) & Rossi & Via Dolomiti \\
\hline Montegranaro (FM) & Franco Gentili & Via Alpi, 16 \\
\hline Porto Sant'Elpidio (FM) & Ripa Shoes & Via Mare Jonio, 9 \\
\hline Montegranaro (FM) & Lilly Fortuna & Via Alpi, 134 \\
\hline Monte San Pietrangeli (FM) & NeroGiardini & Via dell'Artigianato, 6 \\
\hline Montegranaro (FM) & Zeis Excelsa, Oxs, Docksteps & Via Alpi 135/137 \\
\hline Montegranaro (FM) & Alberto Guardiani & Via Alpi \\
\hline Monte San Pietrangeli (FM) & Aldo Bruè & Via Alcide De Gasperi, 9 \\
\hline Montegranaro (FM) & Franceschetti & Via Fermana Nord, 95 \\
\hline Montegranaro (FM) & Carlo Ventura & Via Alpi, 12 \\
\hline Montegranaro (FM) & Fessura & Via Cavallotti, 78 \\
\hline Montegranaro (FM) & Blue Star/Luca Guerrini & Via Pola \\
\hline Montegranaro (FM) & GNV & Via Fiume angolo Via Pola \\
\hline Sant'Elpidio a Mare (FM) & Nando Muzi & Via Faleriense, 2103 \\
\hline Monte Urano (FM) & Carim & Via Carpazi, 15 \\
\hline Monte Urano (FM) & Kelton & Via Urali \\
\hline Monte Urano (FM) & Fabix & Via Italia, 15 \\
\hline Montegranaro (FM) & Mario Bruni & Via Turati, 4 \\
\hline Grottazzolina (FM) & Ocra & Strada Provinciale Girola 3/F \\
\hline Fermo & Giorgio Fabiani & Via Dell'Industria 20 \\
\hline Porto Sant'Elpidio (FM) & Miss Noise & Via dei Consorzi Artigiani, 8 \\
\hline Porto Sant'Elpidio (FM) & Norma J.Baker & SS16 Adriatica, 28 \\
\hline Montegranaro (FM) & Petrocchi & Strada dei Monti, 1 \\
\hline Magliano di Tenna (FM) & Melania & Via Enrico Fermi, 1 \\
\hline
\end{tabular}

\section{Results}

The results obtained from face-to-face interviews are very heterogeneous. In order to place the data collected into its proper context, it is important to report some figures connected to tourist flows concerning the provinces of Macerata and Fermo which represent the investigation field of this study. In 2018 the province of Macerata (336.572 tourist arrivals and 1.560 .159 tourist presences) and Fermo (178.582 tourist arrivals and 1.134.546 tourist presences) registered a total amount of 515.154 tourist arrivals and 2.694.705 tourist presences. The data recorded by the Regional Observatory on Tourism until October 2019 counts 320.015 tourist arrivals and 1.525 .882 tourist presences in the province of Macerata thus registering an increase of over $5 \%$ whereas the numbers concerning the Province of Fermo are of 180.706 tourist arrivals and 1.171.870 tourist presences marking a strong increase compared to the figures reported in 2018 (www.statistica.regionemarche.it).

The sample of interviewed tourists is mainly European $(82 \%)$ and their nationalities are Italian, Dutch, German, Belgian, French and British. The remaining percentage comes from Asia (9\%), North America (5\%), South America (2\%) and Australia (2\%). The data shows a substantial heterogeneity between the three different age groups (18-35, 35-55 and over 55) used to classify the sample. As far as data concerning tourists overnight stays (3-5 days, 7 days and over 7 days) the results share similar percentages. Only $5 \%$ of tourists were one-day visitors and arrived to Macerata and Fermo from another holiday destination. Interviewees were also asked who they were traveling with. Over $40 \%$ were traveling in couple while roughly $25 \%$ were traveling with family and friends. Only a very limited number of visitors were solo travelers, group travelers or on business trip.

All interviewees were asked if it was their first time in Italy or in the Marche. Other two crucial matters for the purpose of this investigation, was understanding whether the visitors had chosen, at least once, a holiday with shopping as its main purpose (regardless of the time and destination of their travel) and if, before choosing their holiday destination, they had made previous researches concerning the presence of shopping facilities (outlets, markets and so on). Data shows that only $7 \%$ of the sample taken into investigation was on 
a shopping trip or had already experienced this type of holiday and that in most cases the top destination had been Paris (18\%) followed by Milan, Rome and London (17\%). The number of interviewees who declared were on a shopping-based trip represents less than $1 \%$ of the entire sample.

A higher percentage of positive answers is recorded in relation to the second question concerning the gathering of information on shopping facilities prior to choosing the holiday destination. Among the tourists that had never undertaken a holiday with shopping as its main purpose, $19 \%$ affirmed they had collected information concerning shopping facilities even though they admitted it was not the main reason for their travel.

Each tourist was also asked information concerning their shopping expenditures. Data was collected concerning the type of goods that had been purchased, prices, number of people intended per expenditure (as a single good can have a multiple number of users), factors in buying and the place of purchase. Most interviewees (85\%) reported purchasing at least one good in the area of study and the average per-capita daily expenditure amounts to 225 Euros. When classifying the average per-capita daily expenditure according to tourists' nationalities, it can be observed that Italians on average spend less (roughly 100 Euros) where as non-European tourists spend almost 30\% more than the general average expenditure. Figures related to European tourists generally show that the average expenditure is slightly below the general average.

Compared to other fellow travelers, people who travel with a partner usually spend more than average (245 Euros). Slightly lower is the average expenditure per-capita of group travelers (230 Euros) where as expenditure concerning family travelers is approximately 100 Euros.

When analyzing the purchased goods, more than half of them (64\%) are clothing and footwear items, $14 \%$ are accessories, jewels and leather items, $18 \%$ are food and wine products and the remaining $4 \%$ are articles belonging to other categories.

To better understand the shopping geography and map out places linked to tourists' purchases, questions were asked on where each good had been bought according to a list of various options (market, city center, shopping streets, shopping center, factory outlet and so on). In Macerata and Fermo data shows that most of shopping activities took place in factory outlet stores specialized in fashion and footwear items. Purchases made in the city center and at local markets, on the other hand, were mainly linked to typical products and souvenirs. Interviewees were also asked questions connected to traveling and shopping in general and in particular, if they considered the Marche as an ideal destination for shopping and if it would be worthwhile returning there for this reason. Less than $60 \%$ of the sample interviewed declared to have found an item they wanted to buy but chose not to mainly due to difficulties concerning its transportation back to the visitors' hometown (approximately $50 \%$ ) or because the price was considered too expensive. Another interesting result worth noticing, is the fact that over $50 \%$ of the interviewees decided to purchase a specific item (in their current travel or in previous ones) on behalf of third parties and it was bought in places like the Marche due to the presence of specific brand productions or unique artisan goods that are hard to find elsewhere or because of favorable purchasing conditions (currency exchange rate or sales).

Despite the fact that shopping was or was not the main purpose of their holiday, seven tourists out of ten recommended the Marche as a shopping destination although $83 \%$ would not return there for shopping-based reasons (83\%). By extrapolating the answers of the interviewees who affirmed they had - at least once - chosen a travel mainly for shopping purposes, the percentage of those who recommended the place are higher (92\%) as well as percentages of those who would return to the same area for purchasing reasons (60\%).

\section{Final Considerations}

The results of this investigation have highlighted the persistent trend of factory outlet stores clustered together in the Marche region, mainly in the area around the towns of Fermo and Macerata where the economical and cultural identity of the place is deeply rooted. This identity finds its further expression in the specialized productive systems of the territory and appeals to national and international tourists more than in the past. The presence of clustered outlet stores adds value to the tourism setting of the region and helps refining the tourist offer.

Contemporary travelers are more informed than before and thus more demanding. Their constant wish for an authentic traveling experience inevitably generates the need to refine the tourist destination with a more specialized and customized offer that meets a wider range of personal needs.

Shopping tourism is becoming an increasing phenomenon which however strongly depends on how the goods sought-after are closely connected to the place in which they are found. The stronger this link, the higher the attractiveness of the destination. In the case of the Marche, the uniqueness of the territory and of its pur- 
chasable goods are fundamental assets in enhancing the pleasantness of tourists' experience.

One of the main challenges for governance bodies today is building a territorial strategy that can further align and interrelate the various segments of the tourism supply/offer so as to foster a communication that promotes a common brand concept for the Marche and is well aware of which are the commercial formats that require most focus. Within this regional destination where different tourist segments converge, it is necessary to further enhance all those real business areas where tourists go seeking an all-round tourist experience.

The times prior the pandemic outbreak seemed ready for the Marche to gear towards a bolder strategic approach by choosing to focus on shopping tourism following the example of other famous international destinations - as a means of further diversifying the local tourist offer.

Although defining the exact scope of this phenomenon as well as clearly identifying all its related stakeholders may not be an easy task, it is nevertheless evident that shopping tourism does represent a segment of the tourist offer on which future tourism planning of the Marche region should focus on.

\section{References}

Alunno, M., Cardinali, S., Fiori, E., Rasicci, C., \& Temperini, V. (2012). Le innovazioni nel commercio. In Gregori, G., Pencarelli, T. (Eds.). Economia, management e disciplina del commercio in Italia e nelle Marche. Milano, FrancoAngeli, 344-394.

Bærenholdt, J.O., Haldrup, M., Larsen, J., Urry, J. (2004). Performing Tourist Places. London, Ashgate.

Betti, S., Nicosia, E., Porto, C.M. (2011). Polycentrism in the Marche Region, a strategic factor for a competitive development in sustainability. In Prezioso, M. (Ed.). Competitiveness in sustainability: the territorial dimension in the implementation of Lisbon/Gothenburg process in Italian Regions and Provinces. Bologna, Pàtron, 197-225.

Choi, M. J. Heo, C. Y. Law, R. (2015). Progress in shopping tourism. Journal of Travel \& Tourism Marketing, 33 (sup1), 1-24, DOI: 10.1080/10548408.2014.969393

Evans, G. (2003). Hard-branding the cultural city - From Prado to Prada. International Journal of Urban and Regional Research, 27 (2), 417-440.

Fondazione Symbola-Unioncamere (28/06/2017). Io sono cultura, Rapporto 2017. https://www.symbola.net/ricerca/ rapporto-io-sono-cultura-2017
Gotham, K. (2002). Marketing Mardi Gras: Commodification, spectacle and the political economy of tourism in New Orleans. Urban Studies, 39 (10), 1735-1756.

Graziano, T. (2019). Outlet e spaccia aziendali nelle Marche: geografie localizzative e nuove narrazioni del territorio. In Nicosia, E. Porto, C.M., Graziano, T. Il commercio nelle aree urbane marchigiane tra vecchi e nuovi format. Milano, FrancoAngeli, 181-207.

Graziano, T., Nicosia, E. (2013). New tourist practices and consumption patterns: the impact of the factory outlet format on the Sicilian tourism sector. In Cirelli, C., Giannone, M., Nicosia, E. (Eds.). Percorsi creativi di turismo urbano - I luoghi dellentertainment nella città del tempo libero. Bologna, Pàtron, 39-52.

Jackson, E.L. (1991). Shopping and leisure: Implication of West Edmonton Mall for leisure and for leisure research. Canadian Geographer, 35 (3), 226-232.

Jackson, P., Thrift, N. (1995). Geographies of Consumption. In Miller, D. (Ed.). Ackowledging Consumption: A Review of New Studies. Londra, New York, Routledge, 204-236.

Jansen-Verbeke, M. (1991). Leisure shopping: A magic concept for the tourism industry?. Tourism Management, 12 (1), 9-14.

Kim, S.S., Timothy, D.J., Hwang, J. (2011). Understanding Japanese tourists' shopping preferences using the decision tree analysis method. Tourism Management, 32 (3), 544-554.

Law, C.M. (2002). Urban Tourism: The Visitor Economy and the Growth of Large Cities. London; New York, Continuum.

McIntyre, C. (2012). Tourism and Retail: The Psychogeography of Liminal Consumption. London, New York, Routledge.

Moscardo, G. (2004). Shopping as a destination attraction: an empirical examination of the role of shopping in tourists' destination choice and experience. Journal of Vacation Marketing, 10 (4), 294-307.

Nicosia, E. (2016). Le luxury shopping streets, spazi urbani del consumo di lusso. Geotema, 51, 132-138.

Nicosia, E., Porto, C. M (2015). Spazi del consumo e nuove polarità commerciali nelle Marche: riflessioni e criticità. In D'Alessandro, L. (Ed.). City, Retail and Consumption. Napoli, Università degli studi di Napoli "L'Orientale", 167-185.

Nicosia, E., Porto, C. M, Graziano, T. (2019). Il commercio nelle aree urbane marchigiane tra vecchi e nuovi format, Milano, FrancoAngeli. 
Perna, A. (2012). Le principali caratteristiche del sistema distributivo delle Marche nel contesto italiano: riflessioni ed evidenze critiche. In Gregori, G., Pencarelli, T. (Eds.). Economia, management e disciplina del commercio in Italia e nelle Marche. Milano, Franco Angeli, 40-71.

Rabbiosi, C. (2011). The invention of shopping tourism. The discursive repositioning of landscape in an Italian retail led case. Journal of Tourism and Cultural Change, 9 (2), 70-87.

Rabbiosi, C. (2013). New itineraries of consumption. Highend factory outlet village between shopping experience and local regeneration. Santarcangelo di Romagna, Maggioli.

Rabbiosi, C. (2015a). Turismo e commercio tra competizione economica e istanze culturali. Il caso della promozione turistica dello shopping a Parigi. Archivio di Studi Urbani e Regionali, 112, 127-146.

Rabbiosi, C (2015b). Renewing a historical legacy: Tourism, leisure shopping and urban branding in Paris. Cities, 42(B), 195-203.

Rabbiosi, C. (2016). Itineraries of consumption: Coproducing leisure shopping sites in Rimini. Journal of Consumer Culture, 16 (2), 412-431. DOI: https://doi. org/10.1177/1469540516635429

Risposte Turismo in collaborazione con ConfturismoConfcommercio (2017). Shopping Tourism Italian Monitor, http://www.shoppingtourismforum.it/stim/

Rojek, C. (2005). Leisure and Tourism. In Calhoun, C., Rojek, C., Turner, B. (Eds). The Sage Hanbook of Sociology. London, Sage, 302-313.

Sciarelli, S., Rossi C. (2007). Turismo e commercio: una sinergia da valorizzare. Economia e diritto del terziario, n. 2, 315-342.

Sfodera, F. (2013). L'esperienza dello shopping per i turisti stranieri. Nuovi modelli di fruizione dei centri storici delle città d'arte. In ISNART (Ed.). Impresa Turismo, Unioncamere, Camere di commercio d'Italia, 231-236.

Snepenger, D.J., Murphy, L., O'Connell, R. (2003). Tourists and residents use of a shopping space. Annals of Tourism Research, 30 (3), 567-580.

Timothy, D. J. (2004). Shopping tourism, retailing and leisure. Clavendon, Channell View Publications.

Timothy, D. J., Butler, R. (1995). Cross-border Shopping. A North American Perspective. Annuals of Tourism Research, 22 (1), 16-34.

Tosun, C. et al. (2007). Tourist shopping experiences and satisfaction. International Journal of Tourism Research, 9 (2), 87-102.
Urry, J., Larsen, J. (2011). The Tourist Gaze 3.0. London, Sage.

Zukin, S. (2004). Point of purchase: how shopping changed American culture. New York, Routledge.

Zukin, S., Smith Maguire, J. (2004). Consumers and consumption. Annual Review of Sociology, 30 (1), 173-197. DOI: 10.1146/annurev.soc.30.012703.110553 